Артур Король, аспірант НПУ імені М.П.Драгоманова

\title{
ІНФОРМАЦІЙНІ ТЕХНОЛОГІї В СИСТЕМІ МІЖНАРОДНИХ ВІДНОСИН: ПРОБЛЕМА ВПРОВАДЖЕННЯ
}

Інформаційно-аналітичне забезпечення зовнішньої політики держави має важливе значення для формування громадської думки різних країн світу, що пов'язане 3 діяльністю державних установ та зовнішньополітичних відомств 3 роз'яснення міжнародній громадськості та урядам зарубіжних країн мети та основних завдань державної політики країни, іï позиції щодо значущих подій міжнародного життя. Майже вся інформаційно-аналітична діяльність пов'язана 3 тим, щоб передбачити певні тенденції і зробити завчасні дії до виникнення тієї чи іншої ситуації. Мета такої діяльності полягає в тому, щоб забезпечити національні інтереси країни у міжнародному співробітництві, захистити інформаційні зв'язки з іншими державами, заявити про свою позицію у світі, здобути інформацію про будь-яку іншу країну. Зовнішньополітичні комунікації охоплюють процес обміну міжнародною інформацією у системі міжнародних відносин між окремими її суб' єктами, між державами, суспільними групами та індивідами [1].

Кожна із інформаційних технологій збирання та використання інформації має свою специфіку щодо іiі змісту. Глобальна мережа Інтернет - це можливість швидко отримувати різноманітну інформацію довідково-фактологічного характеру. Телебачення і радіомовлення $\epsilon$, насамперед, оперативним джерелом повідомлень подієвої спрямованості. Періодичний друк, у свою чергу, поширює інформацію, що більшою мірою містить елементи аналітики, оцінки подій, які відбуваються (особливо це стосується журналів). Видання неперіодичного друку - книги (монографії, дослідження) - можуть дати уявлення про історію тих або інших важливих міжнародних проблем. Пряме спілкування з людьми - носіями інформації- забезпечує здобуття таких відомостей, які практично неможливо отримати за названими вище каналами [2].

Необхідність оволодіння комплексом інформаційних технологій 
збирання та використання інформації випливає із сутності й характеру головних завдань, що постають перед інформаційно-аналітичною роботою дипломатичної служби, оскільки вона зобов'язана постійно забезпечувати державне і політичне керівництво країни якісною інформацією. Насамперед, це стосується аналітичних матеріалів. Якість останніх визначається такими характеристиками, як «достовірність», «повнота», «актуальність». Практична цінність використання інформаційних технологій збирання інформації аналітичних матеріалів дипломатичної служби особливо зростає в тих випадках, коли в них містяться елементи випереджальної інформації, тобто такої, яка дає можливість правильно передбачити або спрогнозувати подальший розвиток політичних подій в певній країні чи цілому регіоні світу. Досвід доводить, що для розуміння нових явищ в різних країнах світу, що мають соціальне, релігійне, національно-етнічне забарвлення, варто вступати в безпосередній контакт 3 представниками відповідних рухів. Саме пряме спілкування здатне не лише дати реальну картину того, якими є плани і цілі таких груп, а й отримати їх вірогідний соціально-політичний, психологічний портрет.

Об'єктивна потреба ефективно працювати 3 оптимально широким набором інформаційних технологій збирання та використання інформації у сучасних міжнародних відносинах робить вкрай актуальним підвищення рівня професійної підготовки співробітників дипломатичної служби. Йдеться як про загальні знання (проблеми сучасної світової економіки, міжнародні відносини у сфері безпеки), так і про більш спеціалізовані предмети, серед яких варто виокремити навички роботи в Інтернеті, а також психологію в ії соціальному й індивідуальному ракурсах [2].

Крім того, нові інформаційні технології збору та використання міжнародної інформації певною мірою зумовлюють загальну трансформацію ролі держави у міжнародних відносинах і впливають на головні форми міжнародних конфліктів. Інформаційна революція призвела до корінного перегляду ролі державного суверенітету і держав у сучасних міжнародних відносинах. Нові реалії інформаційного суспільства вносять зміни не тільки у внутрішню політику різних за рівнем розвитку країн, а й у відносини між ними, у діяльність міжнародних організацій, суспільних рухів, фінансових груп, злочинних угруповань, окремих осіб. Змінюється предмет міжнародних відносин та методи їхньої реалізації, і часто осмислення сучасних 
міжнародних відносин без урахування ролі інформаційних технологій $є$ просто неможливим. Такі якісні зміни повинні мати своє відображення в процесах прийняття зовнішньополітичних рішень.

Новітні інформаційні технології збирання та використання міжнародної інформації роблять міжнародні відносини більш динамічними та непередбачуваними, а національні економіки - більш чутливими до глобальних процесів, що суттєво знижує можливість урядів контролювати інформаційні потоки. Уряди більшості країн нині шукають механізми, які даватимуть змогу пристосовуватися до нових реалій. США, наприклад, переконані в тому, що інформаційне суспільство вже настало, тому необхідно повною мірою скористатися наслідками інформаційної революції як у внутрішній політиці, так і в глобальних масштабах. Країни Західної Свропи орієнтовані передусім на здобуття економічної вигоди за умови збереження існуючих культурних та суспільних цінностей. В Азійсько-Тихоокеанському регіоні цінність інформаційної революції вбачають, насамперед, у можливості економічного зростання та виході на світові ринки в інформаційно-технологічному сегменті. На Близькому Сході правлячі еліти стурбовані можливим впливом інформаційного суспільства на населення і, як свідчать останні роки, небезпідставно [3, 22]. Реалізація кожної із зазначених стратегій потребує застосування не окремої інформаційної технології, а комплексу технологій збирання та використання міжнародної інформації.

У зв'язку з поширенням інформаційних технологій збору та використання інформації в сучасному суспільстві все більшої актуальності набуває проблема захисту інформації в системі міжнародних відносин. Нинішній етап розвитку інформаційних технологій характеризується можливістю масованого інформаційного впливу на індивідуальну та суспільну свідомість аж до проведення великомасштабних інформаційних воєн, в результаті чого неминучою противагою принципу свободи інформації стає принцип інформаційної безпеки. Останній зумовлений глобальною інформаційною революцією, стрімким розвитком і повсюдним впровадженням новітніх інформаційних технологій, глобальних телекомунікаційних засобів.

Як складова розвитку усіх сфер життєдіяльності держав, інформаційна революція розширює можливості розвитку міжнародного співробітництва, формує планетарний інформаційний простір, в якому інформація стає найціннішим елементом національного надбання, 
його стратегічним ресурсом. У сучасному суспільстві інформаційні ресурси, які є основою майже всіх управлінських, економічних та соціальних процесів, набувають домінуючого значення. Постає завдання практичного створення реальних механізмів міждержавної координації і кооперації, комплексу заходів раціонального впровадження сучасних інформаційних технологій, систем та побудови на їх основі міждержавної взаємодії у світовому інформаційному просторі $[4,257]$.

Інформатизація, що формує єдиний світовий інформаційний простір, створюючи глобальне мережеве суспільство, з одного боку, відкриває громадянам охоплених нею країн доступ до всіх матеріальних та духовних благ, множить інтелектуальний ресурс, а, отже, і всі інші ресурси, сприяючи сталому розвитку, досягненню благополуччя, безпеки особистості й суспільства. 3 іншого, - інформаційні технології не $\epsilon$ абсолютним благом: вони створюють нові можливості для контролю й маніпуляції масовою свідомістю у внутрішній політиці, нові ефективні засоби міждержавного протиборства, а, отже, і нові загрози для національної безпеки $[5,8]$. За таких умов загострюється проблема захисту інформації в системі міжнародних відносин.

Інформатизація нині є наймогутнішим інструментом глобалізації. За допомогою інформатизації можна не тільки прискорити розвиток кожної країни, а й перетворити іï на суто маріонеткове утворення. Хоча участь усіх країн світу в процесі інформатизації $\epsilon$ безперечним фактом, втім за своїм рівнем інформаційно-технічного розвитку їх можна поділити на інформаційно багаті та інформаційно бідні. Лідери багатьох держав добре усвідомлюють, що відставання у інформаційних та комунікаційних технологіях може призвести до катастрофічних наслідків. Таким чином, неправильно обрана стратегія інформатизації або іiї недостатній динамізм і мобільність можуть призвести до суттєвих, подекуди драматичних, змін в усіх сферах життєдіяльності країни. Ті, хто вчасно не підготувався для інтеграції у світовий інформаційний простір, ризикують залишитися на периферії історичного розвитку. Отже, поряд 3 позитивними моментами інформатизації виникає реальна загроза використання досягнень в інформаційній сфері для досягнення цілей, несумісних 3 завданнями підтримки світової стабільності й безпеки, дотримання принципів суверенної рівності держав, мирного врегулювання суперечностей і конфліктів, незастосування сили, не- 
втручання у внутрішні справи, поваги прав та свобод людини $[6,1]$.

Головний зміст проблеми захисту інформації в системі міжнародних відносин визначається тим, що в сучасному багатополярному світі інформаційне протистояння є основним засобом забезпечення геополітичного балансу. Мета інформаційного протиборства - забезпечення національних інтересів в інформаційно-психологічній сфері, що охоплює: забезпечення геополітичної і інформаційнопсихологічної безпеки держави; досягнення військово-політичної переваги і безперечного лідерства у сфері міжнародних відносин; забезпечення досягнення цілей національної економічної, ідеологічної, культурної, інформаційно-психологічної експансії; створення сприятливих умов для переходу власної національної системи соціально-політичних відносин на новий, більш високорозвинутий і високотехнологічний рівень еволюційного розвитку; трансформація структури національних економічного, політичного, соціально-культурного, інформаційно-психологічного просторів відповідно до власних принципів формування інформаційної картини світу [7].

Дедалі більше дослідників доходить висновку, що національна безпека окремої країни, побудована на принципах закритих систем, стає неефективною, оскільки глобальні загрози вимагають спільних зусиль, співробітництва, а не конкуренції, на принципах якої побудовано більшість національних систем безпеки. Використання нових інформаційних технологій і засобів впливу високорозвинутих країн на менш технологічні країни світу призвело до зміни глобального та регіонального балансів сили, зумовило нові сфери конфронтації між традиційними й новими центрами глобального протистояння, уможливило досягнення переваг в інформаційних технологіях, у засобах маніпулювання суспільною свідомістю для широкомасштабної експансії із застосуванням не обмежених міжнародним правом видів озброєнь. Водночас до нових інформаційних видів зброї виявляють інтерес як політичні угруповання, так і терористичні та кримінальні організації, що загрожує новим витком гонки озбро$\epsilon н ь$, втратою міжнародних ресурсів для вирішення глобальних проблем бідності, стихійних лих, техногенних катастроф, голоду, епідемій тощо [8, 652].

Усвідомлення загрози через названі вище виклики створює засади теоретичного та практичного обгрунтування системи глобальної інформаційної безпеки, побудованої на відкритості і широкому

ISSN2078-8142 Мультиверсум. Філософський альманах.-2015.-Випуск 3-4(141-142) 63 
співробітництві. Поняття інформаційної безпеки позначає складову загальної системи безпеки особистості, суспільства і держави в інформаційній сфері.

Інформаційна безпека охоплює такі основні проблеми:

- гуманітарного характеру, пов'язані з неправомірним використанням персональних даних громадян, втручанням у приватне життя, дезінформацією;

- економічного та правового характеру, пов'язані з крадіжкою, викривленням інформації, неправомірним використанням інтелектуальної власності, промисловим шпигунством, інформаційними кампаніями, спрямованими на заподіяння шкоди гуманітарного характеру, пов'язані з неправомірним використанням персональних даних громадян, втручанням у приватне життя, дезінформацією;

- політичного характеру, пов'язані з інформаційними війнами, електронною розвідкою, націленою на розкриття державної таємниці, доступом до автоматичних систем управління важливими об'єктами держави, спотворенням інформації, дезінформацією керівників різного рівня державної влади [9, 64-65].

Отже, проблема інформаційної безпеки фактично охоплює всі сфери суспільного та державного життя, оскільки від ії вирішення залежить реалізація національних інтересів будь-якої країни. Відповідно, зазначені вище загальні характеристики інформаційної безпеки зберігають актуальність і для сфери міжнародної інформаційної безпеки. Міжнародна інформаційна безпека найчастіше визначається як взаємодія акторів міжнародних відносин 3 операцій підтримання сталого миру на основі захисту міжнародної інформаційної сфери, глобальної інфраструктури та суспільної свідомості світової спільноти від реальних і потенціальних інформаційних загроз. Таке визначення охоплює всі напрями й усіх суб'єктів міжнародних інформаційних відносин i, таким чином, $є$ повним та логічним у загальнополітичному плані.

Водночас, як зазначає О.Кісілевич-Чорнойван, з позицій юриспруденції, міжнародну інформаційну безпеку доцільніше визначати як стан та умови захищеності міжнародного інформаційного середовища, які забезпечують його формування, використання, розвиток в інтересах акторів міжнародних відносин, включених в це інформаційне середовище, за яких підтримується сталий мир на основі захисту міжнародної інформаційної сфери, глобальної інфраструктури, 
суспільної свідомості світової спільноти від інформаційних загроз. Відповідно, дотримання міжнародної інформаційної безпеки передбачає недопущення (чи мінімізацію) завдання шкоди їхнім інтересам через незаконні дії з інформаційними ресурсами, через негативний інформаційний вплив та негативні наслідки функціонування інформаційних технологій [10].

\section{ЛIТЕРАТУРА}

1. Шевченко O.B. PR-технології формування міжнародного іміджу держави [Електронний ресурс]. - Режим доступу :

http://megalib.com.ua/content/4182_Shevchenko_OV_PR_tehnologii_form yvannya_mijnarodnogo_imidjy_derjavi_html.

2. Извеков Н.Н. Информация и дипломатия [Електронний ресурс]. - Режим доступу : http://evartist.narod.ru/text10/81.htm\#3_03.

3. Вовк Р. Вплив інформаційного суспільства на міжнародні відносини // Вісник Львівського університету. - Серія міжнародні відносини. - 2012. Вип. 30. - С. 18-23.

4. Брижкко B.M. До питання упорядкування діяльності в інформаційній сфері // Открытые информационные и компьютерные интегрированные технологии. - 2009. - №42. - С. 252-259.

5. Брожик Л.Л. Вплив інформатизації на національну ідентичність під час всесвітньої глобалізації // Модернізація та суспільний розвиток економіки країни: Збірник матеріалів Міжнародної науково-практичної конференції (м. Сімферополь, 25-26 січня 2013 року). - Сімферополь, 2013. - C. 7-9.

6. Крылов Г.О. Международный опыт правового регулирования информационной безопасности и его применение в Российской Федерации : автореф. дисс. ... к.ю.н. : 05.13.19; Московский инженерно-физический институт. - М., 2007. -32 с.

7. Набільська Є.M. Інформаційне протистояння як феномен політичної боротьби [Електронний ресурс]. - Режим доступу : http://www.rusnauka.com/16_ADEN_2010/Politologia/68579.doc.htm.

8. Макаренко С.A. Міжнародна інформаційна безпека: Сучасні виклики та загрози. - К., 2006. -916 с.

9. Тамицкий А.М. Информационная безопасность как фактор международных отношений в Арктическом регионе // Вестник Северного (Арктического) федерального университета. - Серия: Гуманитарные и социальные науки. - 2013. - Вып. 6. - С. 63-70.

10. Кісілевич-Чорнойван О.М. Інформаційна безпека та міжнародна інфор- 
маційна безпека: проблема визначення понять [Електронний ресурс]. Режим доступу : http://www.pravnuk.info/2013-12-27-15-12-23/120informacijna-bezpeka-ta-mizhnarodna-informacijna-bezpeka-problemaviznachennya-ponyat.html.

Король А. Інформачійні технології в системі міжнародних відносин: проблема впровадження.

В статті аналізуються зміни в системі інформаційного забезпечення міжнародних відносин, зумовлені глобалізацією та інформаційною революцією. Автор обгрунтовує необхідність впровадження в цю систему новітніх інформаційних технологій, пропонує заходи щодо захисту інформації, забезпечення інформаційної безпеки. Підкреслюється, що міжнародна інформаційна безпека визначається як взаємодія акторів міжнародних відносин з операцій підтримання сталого миру на основі захисту міжнародної інформаційної сфери, глобальної інфраструктури та суспільної свідомості світової спільноти від реальних і потенціальних інформаційних загроз. Проблема інформаційної безпеки фактично охоплює всі сфери суспільного та державного життя, оскільки від ії вирішення залежить реалізація національних інтересів будь-якої країни.

Ключові слова: людина, політика, міжнародні відносини, культура, інформаційні ресурси, демократія.

Король А. Информационные технологии в системе международных отношений: проблема внедрения.

В статье анализируются изменения в системе информационного обеспечения международных отношений, обусловленные глобализацией и информационной революцией. Автор обосновывает необходимость внедрения в эту систему новейших информационных технологий, предлагает меры по защите информации, обеспечения информационной безопасности. Отмечается, что международная информационная безопасность определяется как взаимодействие актеров международных отношений по операциям поддержания устойчивого мира на основе защиты международной информационной сферы, глобальной инфраструктуры и общественного сознания мирового сообщества от реальных и потенциальных информационных угроз. Проблема информационной безопасности фактически охватывает все сферы общественной и государственной жизни, поскольку от ее решения зависит реализация национальных интересов любой страны.

Ключевые слова: человек, политика, международные отношения, культура, информационные ресурсы, демократия.

66 ISSN 2078-8142 Мультиверсум. Філософський альманах.-2015.-Випуск 3-4 (141-142) 
Korol A. Information technology in the system of international relations: problem of implementation.

Changes in the system of information support of international relations caused by globalization and the information revolution were analyzed; author justifies the need to introduce in this system new information technologies, offers measures for information security, ensuring information security; emphasizes that international information security is defined as the interaction of actors of international relations of the operations of sustainable peace based on international information protection sphere, global infrastructure and social consciousness of the international community of real and potential threats to information; information security problem actually covers all areas of social and public life because its solution depends on the realization of national interests of any country.

Key words: human being, politics, international relations, culture, information resources, democracy. 